\title{
A DESCRIPTION OF THE PERSONAL SOCIAL AND SCHOLASTIC BACKGROUND OF NEW STUDENTS FIRST ADMITTED TO THE DEPARTMENT OF NURSING SCIENCE AT MEDUNSA IN 1986, AND THEIR EXPECTATIONS REGARDING THIS UNIVERSITY
}

\author{
C.F. van Niekerk, I. Treadwell, H.M. de Vetta
}

\section{Introduction}

In the past few years the comprehensive biographical questionnaire completed by all students newly admitted to MEDUNSA at the beginning of the academic year, provided valuable information regarding students of the Department of Nursing Science.

The main purpose of this study is to obtain a profile of nursing students, enrolling at Medunsa for the first time, regarding

- their demographic data

- the sociological, economical and educational tendencies in their homes

- their school achievement and

- their expectations of Medunsa.

This information may in future serve to

- compare students' expectations of Medunsa with actual experiences

- compare nursing students with students in medicine and supplementary health services

- provide a base-line for monitoring professional growth.

The questionnaire samples details about the newcomers' personal, social, and scholastic backgrounds and achievements. In addition, the students' expectations of university life in general, and of this university in particular, are gauged.

Presently the survey serves to provide the university authorities and lecturers of the Department of Nursing Science with information about the persons who presented themselves as new students for that year; their background and expectations.

The survey also provides nursing students with a channel for communicating their expectations to the Department of Nursing Science and university authorities.

The present Report is subdivided into four parts:

In Part $\mathrm{A}$ an image is given of the personal backgrounds of the students who presented themselves for the first time at Medunsa in 1986.

In part $B$, background information about the schools from which these students came is provided, as well as information about their subjects and performances at school.

Part C covers the newcomers' expectations of life at this University in respect of lecturers, fellow-students and student life in general.

Part D contains a summary of all the findings of this investigation.

Throughout all four parts of the report, the findings are juxtaposed to those obtained from a corresponding survey done on all students during 1985.

\section{Composition of the 1986 sample}

The sample consisted of students who registered in nursing courses at Medunsa for the first time during the months of January to March 1986. Only 'new students' are included in the sample. Students repeating their first year courses in 1986 have been excluded, as they completed the questionnaire in 1985.

The sample comprises five male and fifty female students. Of the first year students, 18 came to Medunsa immediately from high school, or after a lapse of only a fairly small interval.

The other 37 are students in post-basic Nursing Science who came to further their skills and knowledge in their chosen profession, usually after having worked as a registered nurse for a period of not less than two years. Some have many more than two years experience.

\section{Part a}

BACKGROUND INFORMATION ON THE INTAKE OF NEW NURSING STUDENTS IN 1986

\section{Gender distribution}

The percentages of male and female students, admitted during the period Jan. to March 1986, are as follows:

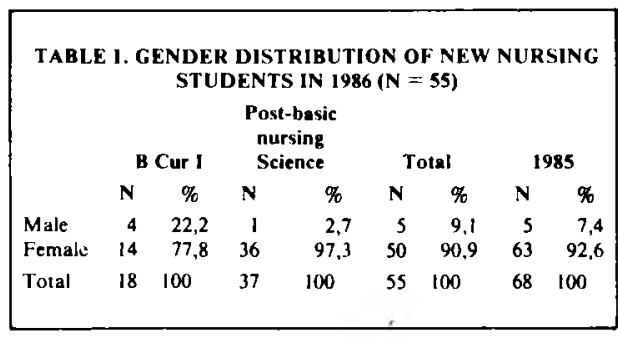

The percentage of male students admitted for the first time increased from $7,4 \%$ in 1985 to $9,1 \%$ in 1986 .

The majority $(90,9 \%)$ of first admission students in 1986 were females.

\begin{tabular}{|c|c|c|c|c|c|c|}
\hline \multicolumn{7}{|c|}{$\begin{array}{l}\text { TABLE 2. DISTRIBUTION OF MALE AND FEMALE } \\
\text { STUDENTS, ADMITTED IN JANUARY TO MARCH } 1986, \\
\text { IN VARIOUS NURSING COURSES }(\mathrm{N}=55)\end{array}$} \\
\hline & \multicolumn{2}{|c|}{ Male } & \multicolumn{2}{|c|}{ Female } & \multicolumn{2}{|c|}{ Total } \\
\hline Course & $\mathbf{N}$ & $\%$ & $\mathbf{N}$ & $\%$ & $\mathbf{N}$ & $\%$ \\
\hline $\begin{array}{l}\text { B Cur I } \\
\text { B Cur (I \& A) }\end{array}$ & 4 & 22,2 & 14 & $\begin{array}{r}77,8 \\
1000\end{array}$ & 18 & $\begin{array}{l}32,7 \\
20\end{array}$ \\
\hline $\begin{array}{l}\text { DNA I } \\
\text { DNA }\end{array}$ & 1 & 9,1 & 10 & 90,9 & 11 & 20 \\
\hline DNE I & - & - & 15 & 100,0 & 15 & 27,3 \\
\hline Total & 5 & 9,1 & so & - & 55 & 10,0 \\
\hline
\end{tabular}

The majority ( $80 \%$ ) of male students in nursing courses enrolled for the B Cur course. This concurs with findings in 1985.

\section{Age distribution}

Table 3 gives the age distribution of the two subgroups of 1986 nursing students separately, as well as the age distribution for the total group.

\begin{tabular}{|lcccc|}
\hline \multicolumn{5}{c|}{ TABLE 3. AGE IN YEARS OF THE 1986 INT AKE OF NEW } \\
STUDENT (N = 55) \\
Age range & B Cur I & Post-basic & Total \\
$15-16$ & N & N & N & $\%$ \\
$17-18$ & 1 & - & 1 & 1,8 \\
$19-20$ & 8 & - & 8 & 14,5 \\
$21-22$ & 2 & - & 7 & 12,7 \\
$23-24$ & - & - & 2 & 3,6 \\
$25-26$ & - & - & - & - \\
$27-28$ & - & 3 & 1 & 1,8 \\
$29-30$ & - & 4 & 4 & 5,5 \\
$31-32$ & - & 6 & 6 & 7,3 \\
$33-34$ & - & 6 & 6 & 10,9 \\
$35-36$ & - & 5 & 5 & 9,9 \\
$37-38$ & - & 1 & 1 & 1,1 \\
$39-40$ & - & 3 & 3 & 5,5 \\
$41-45$ & - & 5 & 5 & 9,1 \\
$46-50$ & - & 2 & 2 & 3,6 \\
$51-55$ & - & - & - & - \\
$56-60$ & - & 1 & 1 & 1,8 \\
Total & 18 & 37 & 55 & 100 \\
Median age & 18.5 yrs & 34,5 yrs & 31,5 & \\
Mean age & 18,6 yrs & 35,5 yrs & 30,0 & \\
& & & & \\
\hline
\end{tabular}

The mean age of B Cur I students is 18,6 years compared to the mean age of 30,0 years of the post-basic students.

\section{Marital status}

Table 4 shows the percentages of single and married students amongst the 1986 intake of new students.

\begin{tabular}{|c|c|c|c|c|}
\hline & $\begin{array}{l}\text { B Cur I } \\
\mathbf{N}\end{array}$ & $\begin{array}{c}\text { Post-basic } \\
\text { Nursing Sc } \\
\text { N }\end{array}$ & $\mathbf{N}$ & Total $\%$ \\
\hline $\begin{array}{l}\text { Single } \\
\text { Married }\end{array}$ & $\begin{array}{r}18 \\
0\end{array}$ & $\begin{array}{l}18 \\
19\end{array}$ & $\begin{array}{l}36 \\
19\end{array}$ & $\begin{array}{l}65,5 \\
34,5\end{array}$ \\
\hline Total & 18 & 37 & 55 & 100 \\
\hline
\end{tabular}

As can be expected all students who are or have been married are post-basic students who are on average 11,4 years older than the B Cur students.

\section{Parents' presence in the family}

The proportion of students' parents who have been reported by the students as to be either living, or deceased and divorced or separated appear in Table 5. 


\begin{tabular}{|lcccccc|}
\hline \multicolumn{8}{|c|}{ TABLE 5. PARENTS LIVING, DIVORCED OR } \\
SEPARATED, AND DECEASED (N = 55) \\
\multicolumn{7}{|c}{ Post-basic } \\
B Cur 1 & Nursing Sc & Total \\
Parents & N & $\%$ & N & $\%$ & N & $\%$ \\
Still living & 9 & 50,0 & 13 & 35,1 & 22 & 40,0 \\
Divorced or separated & 4 & 22,2 & 5 & 13,5 & 9 & 16,4 \\
One parent deceased & 5 & 27,8 & 13 & 35,1 & 18 & 32,7 \\
Both parents deceased & 0 & 0 & 6 & 16,2 & 6 & 10,9 \\
Total & 18 & 100 & 37 & 100 & 55 & 100 \\
& & & & & & \\
\hline
\end{tabular}

Of the total group of students, $49,1 \%$ come from single parent families.

It was found that $22,2 \%$ of B Cur I students, the younger group, came from broken marriages in comparison with $13,5 \%$ of the post-basic group.

\section{Number of brothers and sisters in the home}

\begin{tabular}{|c|c|c|c|c|}
\hline \multicolumn{5}{|c|}{ TABLE 6. SIBI.JNGS IN THE HOME $(\mathrm{N}=55)$} \\
\hline \multirow[b]{2}{*}{ Number of siblings } & \multirow{2}{*}{$\begin{array}{l}\text { B Cur } 1 \\
N\end{array}$} & \multirow{2}{*}{$\begin{array}{l}\text { Post-basic } \\
\text { Nursinz Sc } \\
\text { N }\end{array}$} & \multicolumn{2}{|c|}{ Total } \\
\hline & & & $\mathbf{N}$ & $\%$ \\
\hline 0 & 2 & - & 2 & 3,6 \\
\hline & i & 2 & 3 & 5,5 \\
\hline & 3 & 5 & 8 & 14,5 \\
\hline & 6 & 7 & 13 & 23,6 \\
\hline 4 & 1 & 3 & 4 & 7,3 \\
\hline & 2 & 10 & 12 & 21,8 \\
\hline & 0 & 4 & 4 & 7,3 \\
\hline 7 & $\mathrm{I}$ & 4 & 5 & 9,1 \\
\hline 8 & 2 & 2 & 4 & 7.3 \\
\hline Total & 18 & 37 & 55 & 100 \\
\hline Median & 3 & 5 & 4 & \\
\hline Mean & 3,4 & 4,4 & 4,1 & \\
\hline
\end{tabular}

When comparing the two subgroups, the mean numbers of brothers and/or sisters at home indicate that the younger group of students (B Cur I) come from smaller families (mean $=3,4$ ) compared to the older post-basic students (mean $=4,4$ )

\section{Students' position in the family}

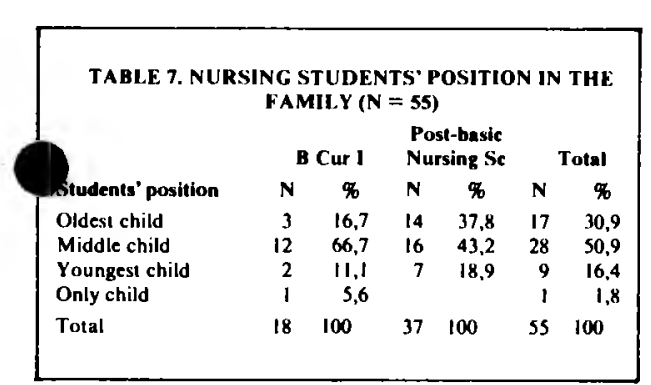

As in the previous year the majority of students $(50,9 \%)$ occupies the middle position in the family. The second strongest group represented the eldest child in the family.

\section{Number of brothers and sisters at university}

\begin{tabular}{|c|c|c|c|c|c|c|}
\hline \multicolumn{7}{|c|}{$\begin{array}{l}\text { TABLE 8. STUDENTS' BROTHERS AND/OR SISTERS AT } \\
\text { UNIVERSITY }(\mathrm{N}=51)\end{array}$} \\
\hline \multirow{2}{*}{$\begin{array}{l}\text { Number of brothers } \\
\text { and/or sisters }\end{array}$} & \multicolumn{2}{|c|}{ B Cur I } & \multicolumn{2}{|c|}{$\begin{array}{l}\text { Post-basic } \\
\text { Nursing Sc }\end{array}$} & \multicolumn{2}{|c|}{ Total } \\
\hline & N & $\%$ & $\mathbf{N}$ & $\%$ & $\mathbf{N}$ & $\%$ \\
\hline 0 & 9 & 50,0 & 25 & 75,8 & 34 & 66,7 \\
\hline 1 & 6 & 33,3 & 4 & 12,1 & 10 & 19,6 \\
\hline 2 & 1 & 5,6 & 2 & 6.1 & 3 & 5,9 \\
\hline 3 & 1 & 5,6 & 2 & 6,1 & 3 & 5,9 \\
\hline 4 & 1 & 5,6 & & & I & 2,0 \\
\hline Total & 18 & 100 & 33 & 100 & 51 & 100 \\
\hline
\end{tabular}

Twice as many B Cur I students $(50 \%)$ have brothers and/or sisters at university compared to the post-basic students $(24,3 \%)$.

The percentage of B Cur I students who have brothers and/or sisters at university have increased from $17,6 \%$ in 1985 to $50 \%$ in 1986 whereas the percentage of postbasic students have decreased from $29,5 \%$ in 1985 to $24,3 \%$ in 1986 .

\section{Parents' educational levels}

The levels of education of the fathers and mothers of all the newly registered nursing students are given in Tabies $\mathbf{9 . 1}$ and 9.2.

\begin{tabular}{|c|c|c|c|c|c|c|}
\hline \multirow[b]{2}{*}{ Educational level } & \multicolumn{2}{|c|}{ B Cur I } & \multicolumn{2}{|c|}{$\begin{array}{l}\text { Post-basic } \\
\text { Nursing Sc }\end{array}$} & \multicolumn{2}{|c|}{ Total } \\
\hline & $\mathbf{N}$ & $\%$ & $\mathbf{N}$ & $\%$ & $\mathbf{N}$ & $\%$ \\
\hline $\begin{array}{l}\text { No education } \\
\text { St } 5 \text { and lower } \\
\text { Lower than Form } 5 \\
\text { (Std. 10) }\end{array}$ & $\begin{array}{l}2 \\
4\end{array}$ & $\begin{array}{l}12,5 \\
25\end{array}$ & $\begin{array}{r}7 \\
12\end{array}$ & $\begin{array}{l}20,6 \\
35,3\end{array}$ & $\begin{array}{r}9 \\
16\end{array}$ & $\begin{array}{l}18,0 \\
32,0\end{array}$ \\
\hline $\begin{array}{l}\text { Matric or equivalent } \\
\text { Post-mutric diploma } \\
\text { University degree or } \\
\text { equivalent }\end{array}$ & $\begin{array}{l}1 \\
1\end{array}$ & $\begin{array}{l}6,3 \\
6,3\end{array}$ & $\begin{array}{l}3 \\
2\end{array}$ & $\begin{array}{l}8,8 \\
5,9\end{array}$ & $\begin{array}{l}4 \\
3\end{array}$ & $\begin{array}{l}8,0 \\
6,0\end{array}$ \\
\hline Other qualifications & - & - & 1 & 2.9 & 1 & 2,0 \\
\hline Total & 16 & 100 & 34 & 100 & 50 & 100 \\
\hline $\begin{array}{l}\text { No father through } \\
\text { divorce, death, } \\
\text { separation }\end{array}$ & 2 & 11,1 & 2 & 3,7 & 4 & 7,3 \\
\hline No response & - & - & 1 & 2.7 & 1 & 1,8 \\
\hline Grand total & 18 & & 37 & & 55 & \\
\hline Total & & & & & & \\
\hline Less than matric & 14 & 87,5 & 29 & 85.3 & 43 & 86 \\
\hline $\begin{array}{l}\text { Std. } 10 \text { and higher } \\
\text { "Other qualifications" }\end{array}$ & 2 & 12,5 & $s$ & 14.7 & 7 & 14 \\
\hline Total & 16 & 100 & 34 & 100 & 50 & 100 \\
\hline Figures for $1985(N=6$ & 68) $v$ & $\begin{array}{l}\text { ere: Le } \\
M\end{array}$ & & $\begin{array}{l}\text { matri } \\
\text { d high }\end{array}$ & & \\
\hline
\end{tabular}

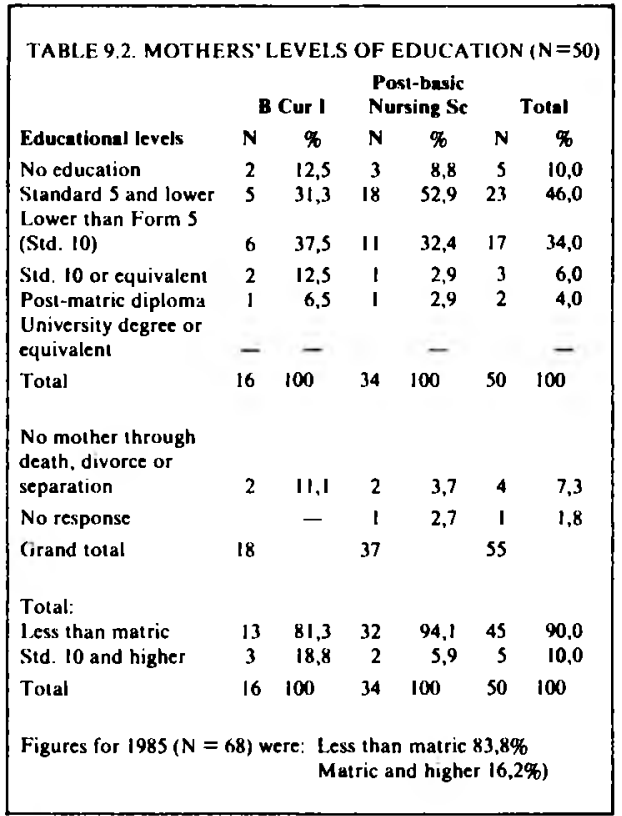

Data in Tables 9.1. and 9.2 shows that:

- an increase has taken place with regard to the educational level of students' fathers (from 14\% Std. 10 and higher in 1985 to $16,2 \%$ in 1986) as well as students' mothers (from $10 \%$ Std. 10 and higher in 1985 to $16,2 \%$ in 1986)
- the education level of $83,8 \%$ of fathers as well as mothers is lower than Std. 10

\section{Parents'occupations}

The distribution of the occupations of parents of the newly registered nursing students is given in Tables 10.1 and 10.2 hereunder.

The findings show that no fathers resort in the professional category.

The percentage of mothers whose occupation fall within the first six categories is higher for the younger B Cur I students $(37,7 \%)$ than for the older postbasic students $(9,6 \%)$.

The largest percentage of fathers in categories 1 to 6 occupy posts in administrative (10\%) and helping services

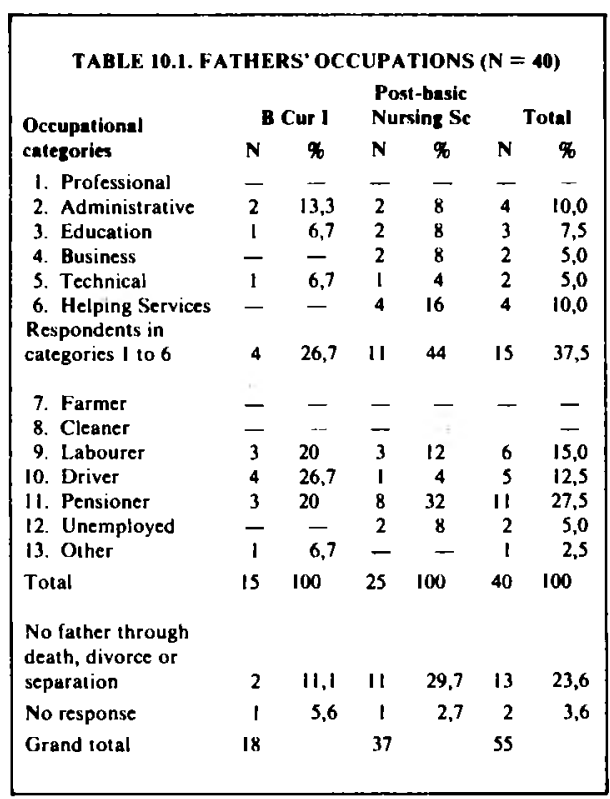

TABLE 10.2. MOTHERS' OCCUPATIONS $(\mathrm{N}=47)$

\begin{tabular}{|c|c|c|c|c|c|c|}
\hline \multirow{2}{*}{$\begin{array}{l}\text { Gccupationai } \\
\text { categories }\end{array}$} & \multicolumn{2}{|c|}{ B Cur I } & \multicolumn{2}{|c|}{$\begin{array}{l}\text { Post-basic } \\
\text { Nursing Se }\end{array}$} & \multicolumn{2}{|c|}{ Total } \\
\hline & $\mathbf{N}$ & $\%$ & $\mathbf{N}$ & \% & $\mathbf{N}$ & \% \\
\hline I. Professional & - & & & - & - & - \\
\hline 2. Administrative & 1 & 6,3 & - & - & 1 & 2,1 \\
\hline 3. Education & 3 & 18,8 & I & 3,2 & 4 & 8,5 \\
\hline 4. Business & 1 & 6,3 & 1 & 3,2 & 2 & 4,3 \\
\hline 5. Helping Services & i & 6,3 & 1 & 3,2 & 2 & 4,3 \\
\hline $\begin{array}{l}\text { Respondents in } \\
\text { categories } \mid \text { to } 5\end{array}$ & 6 & 37,7 & 3 & 9,6 & 9 & 19,2 \\
\hline $\begin{array}{l}\text { 6. Housewife } \\
\text { 7. Cleaner/Domestic }\end{array}$ & 4 & 25 & 18 & 58.1 & 22 & 46,8 \\
\hline serv. & 3 & 18,5 & 5 & 16.1 & 8 & 17,0 \\
\hline $\begin{array}{l}\text { 8. Labourer } \\
\text { 9. Pensioner }\end{array}$ & $\begin{array}{l}2 \\
1\end{array}$ & $\begin{array}{r}12,5 \\
6,3\end{array}$ & $\bar{s}$ & $\overline{16,1}$ & $\begin{array}{l}2 \\
6\end{array}$ & $\begin{array}{r}4,3 \\
12,8\end{array}$ \\
\hline Total & 16 & 100 & 31 & 100 & 47 & 100 \\
\hline $\begin{array}{l}\text { No mother through } \\
\text { death, divorce or } \\
\text { separation }\end{array}$ & 2 & 11,1 & 4 & 10,8 & 6 & 10,9 \\
\hline No response & - & - & 2 & 5.4 & 2 & 3,6 \\
\hline Grand total & 18 & & 37 & & $\$ 5$ & \\
\hline
\end{tabular}

(10\%), while the largest percentage of mothers in categories 1 to 6 is in education $(8,5 \%)(18,8 \% \mathrm{~B}$ Cur and $3,2 \%$ post-basic students).

In categories 7 to 12 the largest proportion of fathers are pensioners $(27,5 \%)$ whilst the largest proportion of mothers are housewives (46\%).

\section{Sources of financial assistance to first year} students

Table 11 overleaf indicates the sources of financial assistance the students have 


\begin{tabular}{|c|c|c|c|c|c|c|c|}
\hline \multicolumn{8}{|c|}{ TABLE II. SOURCES OF FINANCIAL, ASSISTANCE (N = SA) } \\
\hline & \multicolumn{2}{|c|}{ B Cur I } & \multicolumn{2}{|c|}{$\begin{array}{l}\text { Post-basic } \\
\text { Nursing Sc }\end{array}$} & \multicolumn{2}{|c|}{ Total } & \multirow{2}{*}{$\begin{array}{l}x \text { in } 1985 \\
(N=55)\end{array}$} \\
\hline Source & $\mathrm{N}$ & \% & $\mathrm{N}$ & 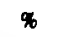 & $\mathbf{N}$ & $\%$ & \\
\hline \multicolumn{8}{|l|}{ Single Source } \\
\hline Parents & 8 & 47,1 & 2 & 5.4 & 10 & 18.5 & 30,8 \\
\hline Guardian & 3 & 17,6 & 3 & 8,1 & 6 & 11.1 & 3,8 \\
\hline Other family relations & - & - & 2 & 5,4 & 2 & 3,7 & 1.9 \\
\hline Friends & - & - & - & - & - & - & - \\
\hline Unconditional bursary & - & - & - & - & - & - & $\mathbf{3 , 8}$ \\
\hline Conditional bursary & - & $\overline{0}$ & 1 & 2,7 & 1 & 1.9 & 26,9 \\
\hline Loan & 4 & 23,5 & 4 & 10,8 & & 14,8 & 1,9 \\
\hline $\begin{array}{l}\text { Selr (including inservice training and } \\
\text { study leave from Dept of } \mathrm{Health}\end{array}$ & - & - & 23 & 62,2 & 23 & 42,6 & 23,1 \\
\hline \multicolumn{8}{|l|}{$\begin{array}{l}\text { Combined Sources } \\
\text { Parents together with: }\end{array}$} \\
\hline $\begin{array}{l}\text { Parents together with: } \\
\text { Guardian }\end{array}$ & - & - & - & - & - & - & 1,9 \\
\hline Other family relations & - & - & - & - & - & - & 1,9 \\
\hline Friends & - & - & - & - & - & - & - \\
\hline Unconditional bursary & - & - & - & - & - & - & - \\
\hline Conditional bursary & - & - & - & - & - & - & - \\
\hline Loan & - & - & - & - & - & - & - \\
\hline $\begin{array}{l}\text { Guardian together with: } \\
\text { Conditional bursary }\end{array}$ & - & - & - & - & - & - & 1,9 \\
\hline Loan & 2 & 11,8 & - & - & 2 & 3,7 & \\
\hline Self & - & - & - & - & - & - & 3,8 \\
\hline Other family relations and: & & & & & & & \\
\hline $\begin{array}{l}\text { Unconditional bursary } \\
\text { Conditional bursary }\end{array}$ & $\bar{z}$ & $\Xi$ & - & -2 & - & $-1,2$ & $\bar{z}$ \\
\hline L.oan & - & - & 1 & 2,7 & 1 & 1,9 & - \\
\hline $\begin{array}{l}\text { Conditional bursary and: } \\
\text { Joan }\end{array}$ & & & & & & & \\
\hline & $z$ & $\bar{z}$ & $\overline{-}$ & $\overline{-}$ & $\overline{-}$ & $\overline{-}$ & 1.9 \\
\hline Total & 17 & & & & 54 & & \\
\hline No response & 1 & & & & 1 & & \\
\hline Total sample & 18 & 100 & 37 & 100 & 55 & 100 & \\
\hline
\end{tabular}

availed themselves of to enable them to enter upon their studies at Medunsa.

On arrival the majority of B Cur students are supported by their parents $(47,1 \%)$ whereas the majority of post-basic students are self-supporting $(62,2 \%)$.

Figures for the total group of 1986 students compared to students of 1985 show:

- an increase in parental support (from $18,5 \%$ to $30,8 \%$ )

- an increase in bursaries (from $1,9 \%$ to $30,7 \%$ )

- a decrease in loans (from $14,8 \%$ to $1,9 \%$ )

- a decrease in self-support (from $42,6 \%$ to $23,9 \%$ ).

\section{Part b}

\section{PROVINCE/LOCATION OF SCHOOL WHERE STUDENTS}

\section{MATRICULATED}

Table 12 indicates the districts of the schools where the new students who came to Medunsa this year matriculated.

Of the $96,2 \%$ of students who matriculated in the RSA the majority of both subgroups matriculated in the Transvaal $(54,7 \%)$.

\begin{tabular}{|c|c|c|c|c|c|c|}
\hline \multirow[b]{3}{*}{ Province/area } & \multirow{2}{*}{\multicolumn{2}{|c|}{ B Cur 1}} & \multirow{2}{*}{\multicolumn{2}{|c|}{$\begin{array}{l}\text { Post-basic } \\
\text { Nursing Sc }\end{array}$}} & \multirow{2}{*}{\multicolumn{2}{|c|}{ Totsl }} \\
\hline & & & & & & \\
\hline & $\mathbf{N}$ & \% & $\mathbf{N}$ & क & $\mathbf{N}$ & $\%$ \\
\hline $\begin{array}{l}\text { Cape Proviace } \\
\text { Natal }\end{array}$ & 1 & 5,9 & $\begin{array}{l}6 \\
3\end{array}$ & $\begin{array}{r}16,7 \\
8,3\end{array}$ & $\begin{array}{l}7 \\
3\end{array}$ & $\begin{array}{r}13,2 \\
5,7\end{array}$ \\
\hline Orange Free State & 5 & 29.4 & 6 & 16,7 & 11 & 20,8 \\
\hline Transvaal & 9 & 52,9 & 20 & 55,6 & 29 & 54,7 \\
\hline SWA Namibia & - & - & 1 & 2,8 & 1 & 1,9 \\
\hline Other & 2 & 11,8 & - & - & 2 & $\mathbf{3 , 8}$ \\
\hline $\begin{array}{l}\text { Total } \\
\text { No response }\end{array}$ & 17 & 100 & $\begin{array}{r}36 \\
1\end{array}$ & 100 & $\begin{array}{r}53 \\
2\end{array}$ & 100 \\
\hline Grand total & 18 & & 37 & & 55 & \\
\hline
\end{tabular}

A verage percentages obtained in final school examinations

Tables 13.1 and 13.2 (Page 11) reflect the average percentages and symbols obtained in matric examination.

The average percentage obtained by the B Cur I students $(55 \%)$ is higher than the average obtained by post-basic students $(49,9 \%)$.

This may indicate a number of phenomena such as:

- an improvement in standards of Black

- a better/more positive reference to

- higher status/desirability of entering in profession. secondary teaching over the past decade nursing by teachers
The percentage of B Cur I students scoring more than $50 \%$ per subject is consistently higher in all subjects than that of the post-basic students. These figures concur with the figures in Table 13.I which indicate a higher average percentage obtained by B Cur I students.

All of the B Cur I students have Mathematics and Physical Science as matriculation subjects whereas only $16,2 \%$ post-basic students have Mathematics and $18,9 \%$ have Physical Science. The greater emphasis placed on Mathematics and Physical Science in the selection of students to Medunsa in 1986 is reflected in the large percentage of students who have these subjects when compared to the percentage of new students in 1985.

- Mathematics $52,7 \%$ in $1986 ; 8,8 \%$ in 1985

- Physical Science $45,5 \%$ in $1986 ; 1,5 \%$ in 1985

\section{Standard repeated at school}

Table 14 (Page 11) show the number of respondents who had to repeat some year(s) in primary or secondary school.

Each of the $23,5 \%$ of B Cur I students who had to repeat a class at school had to repeat Form 5.

A smaller percentage of post-basic students $(19,3 \%)$ had to repeat a class at school in comparison with the B Cur I students $(23,5 \%)$. This could possibly be due to:

- higher standards of evaluation in the past decade

- external factors such as unrest and stay aways.

Part c

\section{STUDY HOURS PER DAY \\ (See Table 15)}

The majority of students $(52,7 \%)$ expect to devote about one hour per day per subject to study. (See Table 16)

The higher percentage of students, $72,2 \%$ B Cur I and $55,6 \%$ post-basic students who expect personal attention to their problems and aid even after hours may be due to:

- expectations of a pedagogic approach as implemented at school level instead of the andragogic approach at universities

- coming from their parents' home (B Cur I)

- having a low self-image (See Table 17)

The majority of the B Cur I students $(55,6 \%)$ look forward to life in a students' residence compared to only 18,9 of the post-basic students.

Post-basic students (45,9\%) mostly view life in a students' residence as possibly interesting although they have their doubts. (See Table 18)

The majority of students $(69 \%)$ in both subgroups feel that the organization of student life in residences should be the shared responsibility of students and the Matron/Boarding Master. (See Table 19)

The matter that concerned most students of both subgroups was whether they would be able to study effectively on their own. 
TABLE: 13.2. SYMBOIS ACHIEVED IN VARJOUS SUBJECTS IN THE FINAL. SCHOOL. EXAMINATIONS: 1986 US 1985 (

$(N-68)$

Subjects and group

English

B Cur :

Post-Basic Nurs. Sc

Total 1986

Total 1985

Mathematics

B Cur I

Post-Basic Nurs. Sc

Total 1986

Total 1985

Physical Science

B Cur I

Post-Basic Nurs. Sc

Total 1986

Total 1985

Biology/Physiology

B Cur

Post-Basic Nurs. Sc.

Total 1986

Total 1985

Other Subjects

B Cur 1

Post-Basic Nurs. Sc

Total 1986

Toial 1985

Afrikaans

B Cur I

Post-Basic Nurs. Sc.

Total 1986

Tolal 1985

Vernacular Language

B Cur 1

Post-Basic Nurs. Sc.

Total 1986

Total 1985

Grand Total 1986

Grand Total 1985

Marks

Number of students who earned these symbols

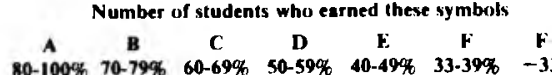

Median E to $\underset{\%}{\text { symbol } F-}$

c.

37

65

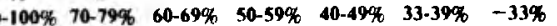

D 33,3

E 62.2

E 54,5

E 58,5

D 27,8

F 83,3

i) 29,2

D-F. 50,0

D/E 50,0

E 100,0

E 64,0

E 100,0

$\begin{array}{lr}\text { D } & 33,3 \\ \text { E. } & 52,4\end{array}$

D 36,7

D 40,0

E 66,7

E 62,1

E 51,4

F. 61,8

35
35

18
32
50
64

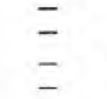

37

37

304

259

GOYK, and over

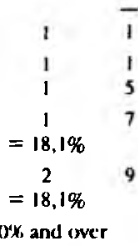

12
13
25
17
47
37

$\begin{array}{cc}6 \\ 10 \\ 16 \\ 21 \\ 97 & 106 \\ 31,9 \% & \\ 82 & 105 \\ 31,7 \% & \\ 50-59 & \end{array}$

/E 38,9

E 78,1

E 32,0

c 0,0

D 32,4

I) 21,8

$\begin{array}{llll}31 & 15 & \text { D/E } 45,1 \\ = & 50 \% & & \end{array}$

E 49,8

under $50 \%$

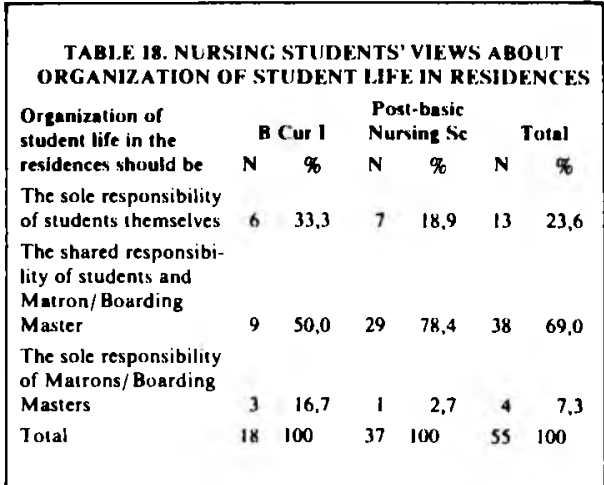

This was followed by their fear of being unable to cope with intimidation from others. These two matters were also most feared by students in 1985 .

\section{Part d}

SUMMARY OF FINDINGS AND CONCLUSIONS

1.Personal and background data of new nursing students in 1986:

1.1 The majority $(90,9 \%)$ of students were females and $80 \%$ of the male students enrolled for the B Cur course. These figures concur with findings in 1985 .

1.2 The mean age of B Cur I students is 18,6 years compared to 30,0 years of the post-basic (students) group.

1.3 All the students who are or have been married are post-basic students.

1.4 When compared with the post-basic students a large percentage of the younger group of students showed Western social tendencies of:

- coming from broken marriages $(22,2 \%)$

- coming from smaller families (4 children in comparison to the 5 children in the older group)

- having a working mother $(75 \%)$.

1.5 The majority of students $(50,9 \%)$ occupy the middle position in the family, while $30,9 \%$ of them are the eldest child in the family.

1.6 The percentage of B Cur I students who have brothers, and/or sisters at university has increased sharply from $17,6 \%$ in 1985 to $50 \%$ in 1986 . being double that of the post-basic students $(24,3 \%)$.

1.7 Although an educational level of Std. 10 and higher amongst the students' mothers has increased from $10 \%$ in 1985 to $16,2 \%$ in 1986 the educational level for both fathers and mothers is still very low $(\mathbf{8 3 , 8 \%}$ lower than Std. 10).

1.8 It is noteworthy that $18,8 \%$ of the B Cur students' mothers are employed in the education field which comes second to the occupation of housewife $(25 \%)$.

1.9 The majority of B Cur students' fathers are drivers $(26,7 \%)$ followed by labourers $(20 \%)$, pensioners $(20 \%)$ and administrative workers $(13,3 \%)$.

1.10 Most B Cur students on arrival are under the impression that they need 
TABIE 19. RANK ORDFR OF MATTERS THAT NEW NURSING STUDENTS FEAR MOST ABOUT LIFE IN A STUDENT RESIDENCE: 1986 VERSUS 1985

\section{Malter}

How to:

Study effectively on my own

Cope with intimidation from others, or their altempts

to physically harm me

Get along with roommate

Lead a satisfactory religious life in a students' residence

Cope with strong drinks and drugs

Cope with university and residence rules

Cope with opposite sex

Cope with diverse other matters

No fears

Total Response

$$
\text { No Response }
$$

Total Samples

\begin{tabular}{|c|c|c|c|c|c|c|c|}
\hline \multirow{2}{*}{\multicolumn{2}{|c|}{ B Cur I }} & \multirow{2}{*}{\multicolumn{2}{|c|}{$\begin{array}{l}\text { Post-basic } \\
\text { Nurs. Sc. }\end{array}$}} & \multicolumn{2}{|c|}{ Total 1986} & \multicolumn{2}{|c|}{ Total 1985} \\
\hline & & & & $(\mathbf{N}=$ & 1 & $\mathbf{l N}=$ & I \\
\hline $\mathbf{N}$ & $\%$ & $\mathbf{N}$ & \% & Renk N & \% & Rank N & $\%$ \\
\hline 10 & 30,3 & 22 & 40 & 32 & 36,4 & 21 & 25,9 \\
\hline 6 & 18.2 & 11 & 20 & 17 & 19.3 & 21 & 25,9 \\
\hline 2 & 6.1 & 11 & 20 & 13 & 14.8 & 15 & 18.5 \\
\hline 5 & 15,2 & 5 & 9.1 & 10 & 11,4 & 12 & 14,8 \\
\hline 6 & 18,2 & 2 & 3,6 & 8 & 9,1 & 6 & 7,4 \\
\hline 2 & 6.1 & 1 & 1,8 & 3 & 3,4 & 3 & 3,7 \\
\hline 2 & 6.1 & & & 2 & 2,3 & - & - \\
\hline - & - & 3 & 5,5 & 3 & 3.4 & 3 & 3.7 \\
\hline & & & & & & - & \\
\hline 33 & 100 & 55 & 100 & 88 & 1000 & 81 & 100 \\
\hline 3 & & 19 & & & & 25 & \\
\hline 18 & & 37 & & & & $\$ 3$ & \\
\hline
\end{tabular}

to be supported by their parents $(47,1 \%)$ or that they require a loan $(23,5 \%)$. Of the post-basic students $62,2 \%$ are self-supporting which includes paid study leave from the

Department of National Health and

Welfare followed by loans $(10,8 \%)$.

When the total group of 1986 students is compared to that of 1985 the figures indicate:

- an increase in financial support by means of parents (from $18,5 \%$ to $30,8 \%$ ) and bursaries ( $1,9 \%$ to $30,7 \%)$

- a decrease in loans (from $14,7 \%$ to $1,9 \%$ ) and self-support (from $42,6 \%$ to $23,1 \%$ ).

2. School achievements

2.1 The majority of students $(52,9 \%)$ matriculated in the Transvaal.
2.2 When comparing matric results the B Cur I students as a group obtained a higher average as well as higher marks for all subjects.

2.3 The proportion of students who have Mathematics and Physical Science has increased tremendously since 1985.

2.4 More B Cur l $(23,5 \%)$ than postbasic students $(19,3 \%)$ had to repeat a class (year) at school. All of this percentage of B Cur students had to repeat matric.

3. Students' expectations of Medunsa

3.1 The majority of students $(52,7 \%)$ expect to devote one hour of study per subject per day.

3.2 A great proportion of B Cur I $(72,2 \%)$ as well as post-basic students $(55,6 \%)$ expect personal attention to their problems even after hours.

3.3 More B Cur I students $(55,6 \%)$ than post-basic students $(18,9 \%)$ look forward to life in a students' residence.

3.4 The majority of students $(69 \%)$ feel that the organization of student life in residences should be the shared responsibility of the students and the Matron or Boarding Master.

3.5 The matters of greatest concern to the students were, as in 1985, firstly whether they would be able to study effectively on their own and secondly, whether they would be able to cope with intimidation.

This report, reflecting the personal, social and scholastic backgrounds and expectations of new students admitted to the Nursing Science Department of Medunsa, will in future be used to compare these students' expectations with their actual experience of life on the campus as well as for comparison with similar data of students admitted in the following years.

Prof C.F. van Niekerk, Dr I. Treadwell Department of Nursing Science Dr H.M. de Velia

Bureau for Student Development and Advice MEDUNSA 